\title{
Expertise of Early Childhood Educators
}

\author{
Iiris Happo \\ $\mathrm{PhD}$, Principal Lecturer \\ University of Applied Sciences, Oulu, Finland \\ E-mail: iiris.happo@oamk.fi \\ Kaarina Määttä \\ PhD, Professor of Educational Psychology \\ University of Lapland, Rovaniemi, Finland \\ E-mail: kaarina.maatta@ulapland.fi
}

Received: February 28, 2011 Accepted: March 10, 2011 doi:10.5539/ies.v4n3p91

\begin{abstract}
Every preschool age child in Finland has the right to day care and the expertise of educators is multidimensional. The aim of this article is to clarify the expertise of those early childhood educators, who have the competence of kindergarten teachers $(n=80)$. The data consisted of the early educators' stories of their growth towards expertise. The analysis was carried out by the methods of content analysis. As the results, three key competences of the informants were created: 1) contextual knowledge, 2) cooperation and communication knowledge, and 3) pedagogical knowledge. This research shows that the educators' work has become more and more collegial and it is necessary to expand a notion of individual expertise into the realm of collaborative and socially shared expertise.
\end{abstract}

Keywords: Expertise, Early educators, Competences, Kindergarten teachers, Professional development

Early childhood education and care can be seen as educational interaction taking place in young children's different living environments. As every preschool age child in Finland has the right to day care, its different forms are the most important area of early childhood activities (Act on Children's Day care, 36/1973; National curriculum guidelines..., 2003). In order to develop these activities, it is important to consider the implementation of early childhood education. The purpose of this article is to clarify expertise of early childhood educators especially in the Finnish context.

In Finland, the system of Early Childhood Education and Care (ECEC) has two main goals. One is to fulfil the preschool age children's day care needs and the other is to provide early childhood education. ECEC may be described with the concept of EduCare, where care, education, and instruction have been combined to form integrated wholeness. (National curriculum guidelines..., 2003) Well-educated staff is one of the strengths of the Finnish day care system. In the day care centres, the term "educator" refers to the staff responsible for care, education, and teaching. In Finland, day care centres have multiprofessional staff and therefore the level of education varies among the staff. The legislation sets out clear requirements for staff qualification. At least one third of the staff must have a post-secondary level degree: Bachelor of Education, Master of Education, or Bachelor of Social Sciences. (Decree on Children's Day care, 239/1973; National curriculum guidelines..., 2003; OECD, 2006) In this study, the target group was early childhood educators from this education level, which were working as kindergarten teachers, special kindergarten teachers, or early childhood educators in day care centres working with $0-7$ year-old children in the province of Lapland.

In the following paragraphs, the literature about expertise and early childhood educators' key competences will be viewed first. After that, the findings of the present study are presented. The key question of this research is: how does the expertise of early childhood educator become tangible in Finland? The material was collected by using a questionnaire, where early childhood educators described their competences under the theme "The story of my growth towards expertise in early childhood education".

\section{Multidimensional Pedagogical Expertise}

Expertise is a concept which is used in many different connections (Ericksson, Chairness, Feltovich, \& Hoffman, 2006). Generally, it refers to the special know-how which is related to different professions (Burnard, 1992; Carter 
et al., 1987; Disch, 2002; Sim \& Kim, 2010; Walker et al., 2010). A certain amount of education and work experience is usually needed for the development into the expert (see also Adelson, 1984). In order to understand the multidimensional pedagogical expertise, we should consider the character of expertise and its principal components. These essential components are practical, formal, and metacognitive knowledge and they complement each other. (Bereiter \& Scardamalia, 1993; Eteläpelto, 1992; Eteläpelto, 1997; Tynjälä, 1999; Tynjälä, 2008; Tynjälä et al., 2006)

Practical knowledge is informal differing from theoretical knowledge (Bereiter \& Scardamalia, 1993; Calderhead, 1984; Tynjälä et al., 2006). At the practical level, knowledge appears as a pragmatic action. It is based on experience and is often acquired in working life. Professionals learn much simply by doing. It means that teachers develop their expertise by teaching. (Tynjälä et al., 2006.)

When people talk about "knowledge" they usually mean formal knowledge and refer to it loosely as "the kind of thing that is found in textbooks". Although it is found in textbooks, it is more than some kind of an abstraction existing in individuals' minds. Formal knowledge is important for communication, teaching, and learning. In order to communicate, experts need a common language with a conceptual similarity. Formal knowledge can also be created in social processes through critical thinking and argumentation. (Bereiter \& Scardamalia, 1993; Tynjälä, 2008.)

Formal knowledge provides the basis of the experts' practical skills. However, one of the major questions is how to translate formal knowledge into informal knowledge and skills. (Bereiter \& Scardamalia, 1993) According to Bereiter and Scardamalia (1993), it seems plausible that formal knowledge is converted into a skill by using formal knowledge to solve procedural problems. Furthermore, formal knowledge is converted into informal knowledge by using formal knowledge to solve comprehension problems. (Bereiter \& Scardamalia, 1993) Problem solving is an inseparable part of pedagogical expertise at every level of knowledge. Hatano and Inagaki $(1986 ; 1992)$ distinguish routine expertise and adaptive expertise from each other. While a routine expert is able to make an efficient and high-quality performance in unchanging situations, the adaptive expert is able to acquit oneself well also in new, constantly changing situations.

The third component of the pedagogical expertise is metacognitive knowledge. It involves self-knowledge and self-assessment. It includes knowledge about where and when to use particular strategies; for example, for learning or problem solving. Rather, it is about knowing how to regulate oneself in order to do a task in a particular way than knowing how to do a task. It is a question of self-regulatory knowledge. (Bereiter \& Scardamalia, 1993; Eteläpelto, 1997; Stenström, 2006; Tynjälä, 2008)

\section{Expertise of Early Childhood Educators}

It is agreed that experts are people who have the ultimate skills and knowledge of their own field. They usually have a long working experience and they are able to use their professional ability in practice. (Eteläpelto, 1992.) In Finland, the experts of early childhood education are professionals in the pedagogical field working mainly in the day care sector in its various forms (National curriculum guidelines..., 2003). Finnish early childhood education comprises care, education, and instruction. However, the know-how included in these areas can also be examined as the separate fields of competences. Early childhood educators' instructional knowledge includes curriculum, content, and pedagogical knowledge. Curriculum knowledge directs an educator to utilize appropriate contents and structure of teaching young children. In addition to a subject to be taught, content knowledge contains the competence of knowing how to teach young children. Pedagogical knowledge contains the choices made in the teaching situation as well as practical action. A pedagogically skilful teacher has exquisite interaction skills. She understands what makes learning easy or difficult and can choose developmentally appropriate practices flexibly during a teaching situation. (Guskey, 1986; Saracho \& Spodekin, 2003)

Ryan and Cooper (2004) present that teachers' self-knowledge and enthusiasm have a significant implication for successful educating and teaching. Successful educational work requires a positive attitude towards children, colleagues, and parents. Especially, children are sensitive to perceive adults' behavior and emotions. (Ryan \& Cooper, 2004) Also van Manen (1991) emphasizes interaction as a part of a good pedagogical process.

The expertise of an early childhood educator is apparently versatile and this phenomenon contains skills and competences of a different kind to be reviewed. According to Karila and Nummenmaa (2001), early childhood educators' competences are contextual knowledge, interaction and cooperation skills, and pedagogical knowledge. In order to improve as an educator, the critical reflection skills are needed as well.

Contextual knowledge contains the understanding about culture and society. Early childhood educators have to be aware of children's and families' living environment and take this into account in their educational work. Interaction and cooperation skills are needed in cooperation with children, families, and partners. A good relationship between 
parents and educators is an essential part of children's well-being and these social skills are inseparable part of educators' work. (Karila \& Nummenmaa, 2001; National Curriculum Guidelines..., 2003)

Early childhood educators' core competence is pedagogical knowledge. In order to be able to improve children's well-being and development, early childhood educators should be aware of the values and goals of education as well as the concept of learning. They should understand the meaning of supporting interaction. However, the understanding of education and concept of learning constantly develops. (Karila \& Nummenmaa 2001; Hirsjärvi 1997) Ryan and Cooper (2004) call the examination and evaluation of one's own work as reflective thinking and emphasize its importance for vocational development. Similarly Costigan and Crocco (2004) stress the significance of reflection for teachers' development. Furthermore, it would be important to use reflective thinking at work starting immediately from the first work year. However, vocational development should continue the whole career. (Costigan \& Crocco, 2004)

\section{Research Questions}

The aim of this study is to clarify the expertise of early childhood educators, who are professionals in that pedagogical field. In Finland, they are working mainly in the day care sector. In this study, the expertise of early childhood educators refers to the knowledge and know-how in the context of the day care.

The key question of this research is:

1. How does early childhood educators' expertise become tangible in Finland?

The main question includes two sub-questions:

\subsection{What does early childhood educators' expertise consist of?}

1.2. What are the main components of early childhood educators' expertise?

\section{Research Method, Data, and Analysis}

The study area was the province of Lapland in Finland. The target group $(n=346)$ comprised the early childhood educators who worked with children in day care and had at least a post-secondary level degree from the field. Because early childhood education is closely connected to pedagogy, the target group consisted of those who had the widest pedagogical education. They were working as kindergarten teachers, special kindergarten teachers or early childhood educators.

The material was collected by using a questionnaire which contained questions for background information and a composition assignment about "The story of my growth towards expertise in early childhood education". The questionnaire was sent to the whole target group ( $\mathrm{n}=346)$. The data was gathered during the years 2003 and 2004 .

Eighty (80) early childhood educators participated in the study and sent their story by mail. Seventy seven (77) of them were women and three (3) men. The participants were aged between 25 and 55 years. 45-49 year-old participants formed the biggest group $(n=24)$. The youngest participants were $25-29$ years old $(n=6)$ and the oldest ones over 55 years old $(n=9)$. Seven (7) of them were 30-34 years old, twelve (12) 35-39 years old, twelve (12) 40-44 years old, and ten (10) 50-54 years old.

The study had a qualitative approach. The data collection method consisted of the early childhood educators' stories of their growth towards expertise. Altogether, the data was comprised of 311 sheets of written text. The analysis was carried out by the methods of content analysis, which entailed a systematic reading of the body of texts. The analysis of the research data began by searching the elements of their knowledge related to their own work from the early childhood educators' own descriptions.

At the first stage, the analysis was based on the Karila's and Nummenmaa's (2001) framework of the early childhood educators' knowledge. The analysis of the research material was based on a preconception of the phenomenon and on a theory and, thus, can be defined as an abductive reasoning. Along with the analysis, three main fields of knowledge could be distinguished: 1) contextual knowledge, 2) cooperation and communication knowledge and 3) pedagogical knowledge.

Therefore, the initial analysis was based on Karila's and Nummenmaa's (2001) framework of early childhood educators' knowledge. Thereafter, the analysis proceeded in a data-based or inductive manner: first with the reduction of data and next by clustering the data.

\section{Results}

\subsection{Expertise of Early Childhood Educators}

The early childhood educators described many different ways how their expertise becomes tangible in their work. They had competences which assisted the goal-oriented rearing. In this study, based on Karila's and Nummenmaa's (2001) research and the informants' stories, the following three key competences were created: 


\section{1) Contextual knowledge,}

2) Cooperation and communication knowledge, and

3) Pedagogical knowledge.

The findings of the study will be reported in the following paragraphs based on the early childhood educators' stories about their key competences and expertise. The contextual knowledge will be considered at first and next the cooperation and communication knowledge. The main issue is pedagogical knowledge which is subdivided into three different levels: direct knowledge, indirect knowledge and awareness knowledge in early childhood education.

\subsection{Contextual Knowledge}

Expertise always comes true in some context. In this research, the operational environment was the day care units in the province of Lapland in Finland. The implementation is guided not only by national regulations and policy documents but also by the instructions of the municipality and the particular day care centre. It is worth noticing a child's past and present growing environment as well. The early childhood educators described all these factors in their stories. In this research, their contextual knowledge consisted of societal awareness, organizational know-how, and the perception of a child's growing context.

Contextual knowledge and early childhood education are related to each other at the social level. The educators were aware of the social significance of the early childhood education and day care. This societal awareness came tangible in educators' stories. They were aware of how the values of the society influence on the appreciation of early childhood education and on the educators' rearing work as well. Social changes have affected families' welfare and have also placed some new requirements to the educators' know-how.

The early childhood educators also needed organizational know-how. They had to perceive their work as a part of the whole day care centre and as a part of the municipal system. At municipalities there were different kinds of working groups in which the educators participated. Organizational development was one of their competences.

"It's not enough that as a kindergarten teacher you just potter around with the children and families of your own group. The work extends much more beyond." (61)

One important part of the contextual knowledge was the perception of a child's growing context. A child's growth and development are influenced from many different directions. Cooperation between educators and parents must be intensive. Many of the educators described their relationship with the parents as a partnership referring to a mutual, continuous and committed interaction concerning the children. The early childhood educators were conscious of its significance.

"The child doesn't grow by the influence gotten at home or at day care but by the synergy in which also the indirect influences are directed." (40)

\subsection{Cooperation and Communication Knowledge}

Early childhood education and care consist of educational interaction between children and educators. It is also a partnership between parents and staff which means a conscious commitment to collaboration for children's growth, development, and learning.

Early childhood educators need good skills and a wide knowledge of cooperation and communication. The informants described the multi-professional networking and cooperation with parents being part and parcel of their job. They might cooperate, for example, with a physiotherapist, social worker, special teacher, or psychologist. They also worked with administrative staff. However, the cooperation with parents had priority.

"I consider interaction with the parents as especially important for my successful working." (24)

As cooperation and communication are an inextricable part of educators' work, they need excellent cooperation and communication skills. It is challenging to illustrate the skills needed at cooperation and communication, because it is such a multidimensional phenomenon. However, the early childhood educators were able to lively picture their ways of cooperation and communication. They were empathic, flexible, social, and persistent. They also had a sense of humour and plenty of courage. They had a good contact with parents and other professionals and they could create a safe atmosphere where presence, active listening, and appreciation were possible. Most of the informants emphasized the significance of those skills at their work and also described these skills as an inseparable part of the pedagogical knowledge.

"I listen to all parties and try to suggest solutions that would satisfy everyone." (5)

\subsection{Pedagogical Knowledge}

The pedagogues included all those elements which are part of a child's and an adult's target-oriented interaction. The early childhood educators described their pedagogical knowledge as multiform and according to their stories pedagogical knowledge could be divided into the following levels: 
1) Knowledge at the direct level, which appears in immediate interaction with the children,

2) Knowledge at the indirect level, which is mainly theoretical knowledge or planning work which supports education indirectly, and

3) Knowledge at the level of awareness, which includes for example the values or ethics of education.

\subsection{The Pedagogical Knowledge at the Direct Level}

The pedagogical knowledge at the direct level means all those pedagogical operations that take place in an immediate interaction between a child and an adult. In the early childhood educators' stories, interaction was emphasized at the direct level of pedagogical knowledge. The educators brought out specifically the importance of educational interaction with children. According to the educators, interaction should be target-oriented and ethical. The quality of an interaction was a meaningful part of pedagogical knowledge and it was important to pay attention to the children and to take care of them. The significance of actual presence was also emphasized.

"I'm present; I listen to the children and don't teach and rear them until they are breathless. I let them live like a child in peace." (4)

The pedagogical knowledge at the direct level included also pedagogical skills. According to the informants, those skills emerged in the social situations with the children. According to the educators' stories, pedagogical skills included supporting the children's functional development, motivating skills, implementation of teaching and guiding as well as using appropriate teaching methods. In addition, having a control over a group of children was a necessary pedagogical skill.

"It is also important to invoke interest and curiosity." (40)

"Support and encouragement are needed as well as appreciation and recognition for good job." (40)

The majority of the early childhood educators described that having personal favourable skills or features was an advantage in their work as an educator. For example, involvement with children, consistency, gentleness, and patience were such features of the personality. These personal characteristics helped the educators in their target-oriented interaction between the children and adults. In addition, different kind of proficiency in different areas was considered useful; for example, using musicality, sportive skills, and manual skills in the immediate interaction.

"I'm an all-rounder at sports. I'm especially interested in nature and hiking in the wilds. It reflects in my work quite strongly. We go for adventures and trek in the wilds weekly." (54)

\subsection{The Pedagogical Knowledge at the Indirect Level}

According to the participants' stories, the second level of pedagogical knowledge was an indirect level. This level does not occur in the immediate interaction with children, but educators' work at this level support achieving the educational goals. Early childhood educators' pedagogical knowledge included know-how needed for building an appropriate and safe environment. They also needed the knowledge for planning the implementation of the curriculum. This level of pedagogical knowledge includes a variety of theoretical knowledge.

The educators emphasized the meaning of safety. At this indirect level, goal-oriented education was fostered by both mental and physical security. Goal-oriented education cannot succeed until children feel secure and their basic needs are satisfied.

"The starting point to everything is a secure environment and all the basic functions are in a state (eat well, rest well, etc.)" (40)

"The need for rest and calming down is emphasized, proximity and tenderness are important, listening and relaxed atmosphere makes us all feel better and enjoying our stay at the day-care centre." (27)

The early childhood educators also described that in order to be an excellent educator you need to know the legislation, national regulations, policy documents and instructions as well as the instructions of the municipality. Thus, at this indirect level, goal-oriented education could be described as being led by external work counselling.

"Nowadays, early education is more consistent than before because it is based on the national curriculum." (40)

At the indirect level, goal-oriented education was also fostered by the educators' planning and coordination. The early childhood educators need to know the theory of child's development. They described that while education, teaching, and different kind of pedagogical methods were on their responsibility, the implementation should be well planned and the whole day smoothly coordinated. 
"My task as a kindergarten teacher involves accounting for the planning and implementation of teaching, rearing, and nursing in the group." (33)

\subsection{The Pedagogical Knowledge at the Level of Awareness}

According to their stories, the early childhood educators were reliable and reflective workers. They were thinking and reflecting their pedagogical methods and pedagogical choices continuously. The educators were aware of their knowledge of rearing, child-orientation, and individuality as well as their responsibility being the key elements at the level of awareness. As this level affected the implementation of education, it could also be referred as metacognitive skills.

Nearly every educator emphasized the responsibility in their rearing work. They described that they are responsible for everything during a day. The implementation of the rearing work was the main issue, but they also were responsible for affecting children's affairs generally.

"I'm responsible for my own child group, the children in it, the staff, the activities, that have to be based on the curriculum of the day-care centre, the pedagogical instruction; noticing the developmental disorders in children and the talented children as well." (67)

"I'm responsible for everything that concerns preschool age children; the goals of early education, preschool education, among others, every child/family's needs separately, the whole group." (14)

Child-orientation and individuality were highlighted in the educators' stories. The early childhood educators wanted their educating and teaching to be based on those values. They were aware of the meaning of child-orientation and individuality and their intention was to realize those set of values in immediate interaction with children at the direct level of pedagogical knowledge. The educators respected each child's individuality. At this level, it is also a question about the self-regulatory knowledge of the educator.

"I notice the children as individuals and try to take their individualistic needs into consideration." (32)

The third key element at the level of awareness was educational knowledge. The educators became aware of their concept of learning and appropriate methods for children. Early childhood educators described their thoughts about good care, education, and teaching. They also told their opinions on the targets of education and day care as well as on children's good life.

"I can find and came up with something new from a child's everyday life. I think that I've internalized the constructivist idea of learning quite well and can implement it in the everyday life, at least most of the time. I consider comprehensive teaching as good, something from that old Fröbelism." (49)

To sum up, pedagogical knowledge could be divided into the levels of direct knowledge, indirect knowledge, and awareness knowledge. In education and teaching, all these levels are essential and complement each other. An expert educator manages all three components of pedagogical knowledge at every level of teaching and is able to act appropriately in different contexts.

\section{Conclusions}

In this research, the concept of the early childhood educator's expertise was studied within the framework of 1) contextual knowledge, 2) cooperation and communication knowledge, and 3) pedagogical knowledge. Contextual knowledge comprised societal awareness, organizational know-how, and the perception of a child's growing context. Cooperation and communication knowledge covered multi-professional networking, cooperation with parents, and excellent cooperation and communication skills which were considered essential for the educators' context knowledge as well. Pedagogical knowledge could be divided into the levels of direct knowledge, indirect knowledge, and awareness knowledge in early childhood education. At the direct level of pedagogical knowledge, educational interaction with children was emphasized. At the indirect level, target-oriented education was fostered by planning, coordination, external work counselling, and both mental and physical security. Responsibility, educational knowledge and child-orientation as well as individuality were seen as the key elements of the educators' awareness knowledge.

A deep reflection on work helps educators to perceive and evaluate their educational action. According to Wood and Bennet (2000), teachers who are engaged in the reflection process of their everyday practical problem-solving strategies and pedagogical interactions, are able to articulate their professional knowledge and obtain a deeper understanding about their theories and practice. At the metacognitive level, early childhood educators need reflection skills to analyze their practical action and theoretical knowledge. The metacognitive level can be compared with the level of awareness of pedagogical knowledge. It involves self-knowledge and self-assessment and includes knowledge about where and when to use particular strategies; for example, for learning or problem 
solving. Rather, it is about knowing how to regulate oneself in order to do a task in a particular way than knowing how to do a task. It is a question of self-regulatory knowledge. (Bereiter \& Scardamalia, 1993; Eteläpelto, 1997; Stenström, 2006; Tynjälä, 2008) (See Figure 1)

Expertise consists of different levels. Development into an expert is an individual process and each professional need to find their own path of development. In order to develop, early childhood educators have to be able to reflect their work. According to Blay and Ireson (2009), there is a link between teachers' pedagogical beliefs and their classroom practices. That is why reflection should take place at every level of early childhood education daily (see Figure 1). However, educators' work has become more and more collegial. Co-workers learn from each other and joint problem solving in the work community is increasing. It is necessary to expand the notion of individual expertise in the realm of collaborative and socially shared expertise.

\section{Discussion}

The principal components of pedagogical expertise are practical, formal, and metacognitive knowledge. At the practical level, the early childhood educators' pedagogical knowledge appears as a pragmatic action. Practical knowledge is rather intuitive. It is parallel by the direct level of early childhood education, which includes educational interactional skills, pragmatic pedagogical skills, and is influenced by educators' own personal characteristics. This practical knowledge is based on experience. It develops step by step and can be gained through practical experiences. (Bereiter \& Scardamalia, 1993; Happo, 2006; Tynjälä et al., 2006.)

At the formal level, the theoretical knowledge about education is essential and can be easily explicated, for example in books. It can be compared with the indirect level of early childhood education. This level comes true before or after direct interaction with children, when educators for example plan, coordinate, or develop their rearing work. Early childhood educators need a common conceptualization of education in order to develop practices and create new ones. In rearing work, they also need to convert their formal knowledge into practical action. (Bereiter \& Scardamalia, 1993; Happo, 2006; Tynjälä et al., 2006)

The pedagogical know-how is early childhood educator's core competence as it represents educators' substance field. Early childhood educators' pedagogical knowledge includes advanced educational knowledge and know-how, for example safety, appropriate environment, curriculum, didactics, and the pedagogy of teaching as well as educational interaction. The implementation of early childhood education is a multidimensional phenomenon that consists of for example planning, carrying out, and evaluating learning processes. Educators should be able to consider many aspects: managing appropriate teaching and guiding methods, organizing learning environment, and perceiving the children with special needs among other things. (See e.g. Bredekamp \& Willer, 1992; Guskey, 1986; Happo, 2006; Olson, 1994; Puckett \& Diffily, 1999; Saracho \& Spodek, 2003)

Expertise can be collectively created through the processes of reflective dialogue (Allen \& Casbergue, 1997). Beginning educators need support especially to solve pedagogical problems at every level and in order to develop the work community; experienced colleagues should mentor novices (Tochon \& Munby, 1993). A mentor's roles as a listener, supporter, encourager and role model help a novice teacher to focus teaching on children's learning and appropriate practices (Bartell, 2004; Reilly, 2008).

\section{References}

Act on Children's Day-care (36/1973). Finlex database. [Online] Available: http://www.finlex.fi/fi/laki/ajantasa/1973/19730036?search\%5Btype\%5D=pika\&search\%5Bpika\%5D=laki\%20laste n\%20p\%C3\%A4iv\%C3\%A4hoidosta

Adelson, B. (1984). When novices surpass experts: The difficulty of a task may increase with expertise. Journal of Experimental Psychology: Learning, Memory, and Cognition, 10 (3), 483-495

Allen, R.M., \& Casbergue, R.M. (1997). Evolution of novice through expert teachers' recall: Implications for effective reflection on practice. Teaching and Teacher Education, 13 (7), 741-755

Bartell, C. A. (2004). Cultivating high-quality teaching through induction and mentoring. California: Sage.

Bereiter, C., \& Scardamalia, M. (1993). Surpassing ourselves. An inquiry into the nature and implications of expertise. Chicago, IL: Open Court.

Blay, J. A., \& Ireson, J. (2009). Pedagogical beliefs, activity choice and structure, and adult-child interaction in nursery classrooms. Teaching and Teacher Education, 25(8), 1105-1116

Bredekamp, S., \& Willer, B. (1992). Of ladders and lattices, cores and cones: conceptualizing an early childhood professional development system. Young Children National Association for the Education of Young Children, 47(3), $47-50$ 
Burnard, P. (1992). Expert to novice. Nurse Education Today, 12 (5), 321-322

Calderhead, J. (1984). Teachers' classroom decision-making. Great Britain: Billing \& Sons Limited, Worcester.

Carter, K., Sabers, D., Cushing, K., Pinnegar, S., \& Berliner, D.C. (1987). Processing and using information about students: A study of expert, novice, and postulant teachers. Teaching and Teacher Education, 3 (2), 147-157

Costigan, A. T., \& Crocco, M. S. (2004). Learning to teach in an age of accountability. New Jersey: Lawrence Erlbaum Associates.

Decree on Children's Day care (239/1973). Finlex database. [Online] Available: http://www.finlex.fi/fi/laki/ajantasa/1973/19730239?search\%5Btype\%5D=pika\&search\%5Bpika\%5D=asetus\%20la sten $\% 20 \mathrm{p} \% \mathrm{C} 3 \% \mathrm{~A} 4 \mathrm{iv} \% \mathrm{C} 3 \% \mathrm{~A} 4$ hoidosta

Disch, J. (2002). From expert to novice. Journal of Professional Nursing, 18 (6), 310

Ericsson, K., Chairness, N., Feltovich, P.J., \& Hoffman, R.R. (Eds.). (2006). The Cambridge handbook of expertise and expert performance. Cambridge: Cambridge University Press.

Eteläpelto, A. (1992). Asiantuntijuuden kehittäminen ammattikorkeakoulun haasteena [The Development of Expertise as a Challenge for a Polytechnic]. In J. Ekola (Ed.), Johdatusta ammattikorkeakoulupedagogiikkaan [Introduction to Pedagogy at Polytechnic] (pp. 19-42). Porvoo, Finland: WSOY.

Eteläpelto, A. (1997). Asiantuntijuuden muuttuvat määritykset [The Changing Definitions of Professionalism]. In J. Kirjonen, P. Remes, \& A. Eteläpelto (Eds.), Muuttuva asiantuntijuus [Changing Professionalism] (pp. 86-102). Jyväskylä, Finland: Finnish Institute for Educational Research.

Guskey, T. R. (1986). Staff development and the process of teacher change. Educational Researchers, 15(5), 5-12

Happo, I. (2006). Varhaiskasvattajan asiantuntijuus. Asiantuntijaksi kehittyminen Lapin läänissä [Expertise of Early Childhood Educators. Growth of Expertise in Early Childhood Educators in the Province of Lapland]. Acta Universitatis Lapponiensis 98. Rovaniemi, Finland: University of Lapland.

Hatano, G., \& Inagaki, K. (1986). Two courses of expertise. In H. Stevenson, H. Azuma, \& K. Hakuta (Eds.), Child development and education in Japan (pp. 262-272). New York: W.H. Freeman.

Hatano, G., \& Inagaki, K. (1992). Desituating cognition through the construction of conceptual knowledge. In P. Light, \& G. Butterworth (Eds.), Context and cognition: ways of knowing and learning (pp. 115-133). New York: Harvester Wheatsheaf.

Hirsjärvi, S. (1997). Kasvatustietoisuus [Educational Consciousness]. In S. Hirsjärvi, \& J. Huttunen (Eds.), Johdatus kasvatustieteeseen [Introduction to the Science of Education] ( $4^{\text {th }}-5^{\text {th }}$ ed.) (pp. 60-62). Juva, Filnand: WSOY.

Karila, K., \& Nummenmaa, A. R. (2001). Matkalla moniammatillisuuteen Kuvauskohteena päiväkoti [A the Way Towards Multiprofessionalism: Day Care Centre as the Target of Depiction]. Helsinki, Finland: WSOY.

National Curriculum Guidelines on Early Childhood Education and Care in Finland. (2003). Guidelines 56. Helsinki, Finland: Statistics Finland. [Online] Available: http://kasvunkumppanit.thl.fi/thl-client/pdfs/267671cb-0ec0-4039-b97b-7ac6ce6b9c10 (February 6, 2011)

Olson, G. (1994). Preparing early childhood educators for constructivist teaching. In S. G. Goffin, \& D. E. Day (Eds.), New perspectives in early childhood teacher education: Bringing practitioners into the debate (pp. 37-47). New York: Teachers College Press.

Puckett, M. B., \& Diffily, D. (1999). Teaching young children: An introduction to the early childhood profession. Orlando: Harcourt Brace \& Company.

Reilly, R. C. (2008). Is expertise a necessary precondition for creativity? A case of four novice learning group facilitators. Thinking Skills and Creativity, 3, 59-76. [Online] Available: http://www.sciencedirect.com (February 16, 2011)

Ryan, K., \& Cooper, J. M. (2004). Those who can, teach (10 ${ }^{\text {th }}$ ed.). Boston: Houghton Mifflin Company.

Saracho, O. N., \& Spodek, B. (2003). The preparation of teachers for the profession in early childhood education. In O. N. Saracho, \& B. Spodek (Eds.), Studying teachers in early childhood settings (pp. 1-28). Greenwich, CT: Information Age Publishing.

Sim, M., \& Kim, Jin-Uk. (2010). Differences between experts and novices in kinematics and accuracy of golf putting. Human Movement Science, 29(6), 932-946. doi:10.1016/j.humov.2010.07.014, http://dx.doi.org/10.1016/j.humov.2010.07.014 
OECD. (2006). Starting strong II: Early childhood education and care. [Online] Available: http://www.oecd.org/document/56/0,3746,en_2649_39263231_37416703_1_1_1_1,00.html\#ES (February 14, 2011)

Stenström, M.-L. (2006). Polytechnic graduates' working-life skills and expertise. In P. Tynjälä, J. Välimaa, \& G. Boulton-Lewis (Eds.), Higher education and working life: Collaborations, confrontations and challenges (pp. 89-102). Amsterdam: Elevier.

Tochon, F., \& Munby, H., (1993). Novice and expert teachers' time epistemology: A wave function from didactics ton pedagogy. Teaching and Teacher Education, 9(2), 205-218

Tynjälä, P. (1999). Konstruktivistinen oppimiskäsitys ja asiantuntijuuden edellytysten rakentaminen koulutuksessa [The constructivist idea of learning and creating the prerequisites of expertise in education]. In A. Eteläpelto, \& P. Tynjälä (Eds.), Oppiminen ja asiantuntijuus. Työelämän ja koulutuksen näkökulmia [Learning and expertise: Perspectives of working life and education] (pp. 160-179). Porvoo, Finland: WSOY.

Tynjälä, P. (2008). Perspectives into learning at the workplace. Educational Research Review, 3(2), $130-154$. [Online] Available: http://www.sciencedirect.com (February 16, 2011)

Tynjälä, P., Slotte, V., Nieminen, J., Lonka, K., \& Olkinuora, E. (2006). From university to working life: Graduates' workplace skills in practice. In P. Tynjälä, J. Välimaa, \& G. Boulton-Lewis (Eds.), Higher education and working life: Collaborations, confrontations and challenges (pp. 73-88). Amsterdam: Elsevier.

Walker, G.H., Stanton, N. A., Salmon, P.M., Jenkins, D. P., Rafferty, L., \& Ladva, D. (2010). Same or different? Genralism from novices to experts in military command and control studies. International Journal of Industrial Ergonomics, 40 (5), 473-483. doi:10.1016/j.ergon.2010.04.003, http://dx.doi.org/10.1016/j.ergon.2010.04.003

Van Manen, M. (1991). The tact of teaching. The meaning of pedagogical thoughtfulness. Albany, NY: State University of New York Press.

Wood, E., \& Bennet, N. (2000). Changing theories, changing practice: exploring early childhood teachers' professional learning. Teaching and Teacher Education, 16(5-6), 635-647

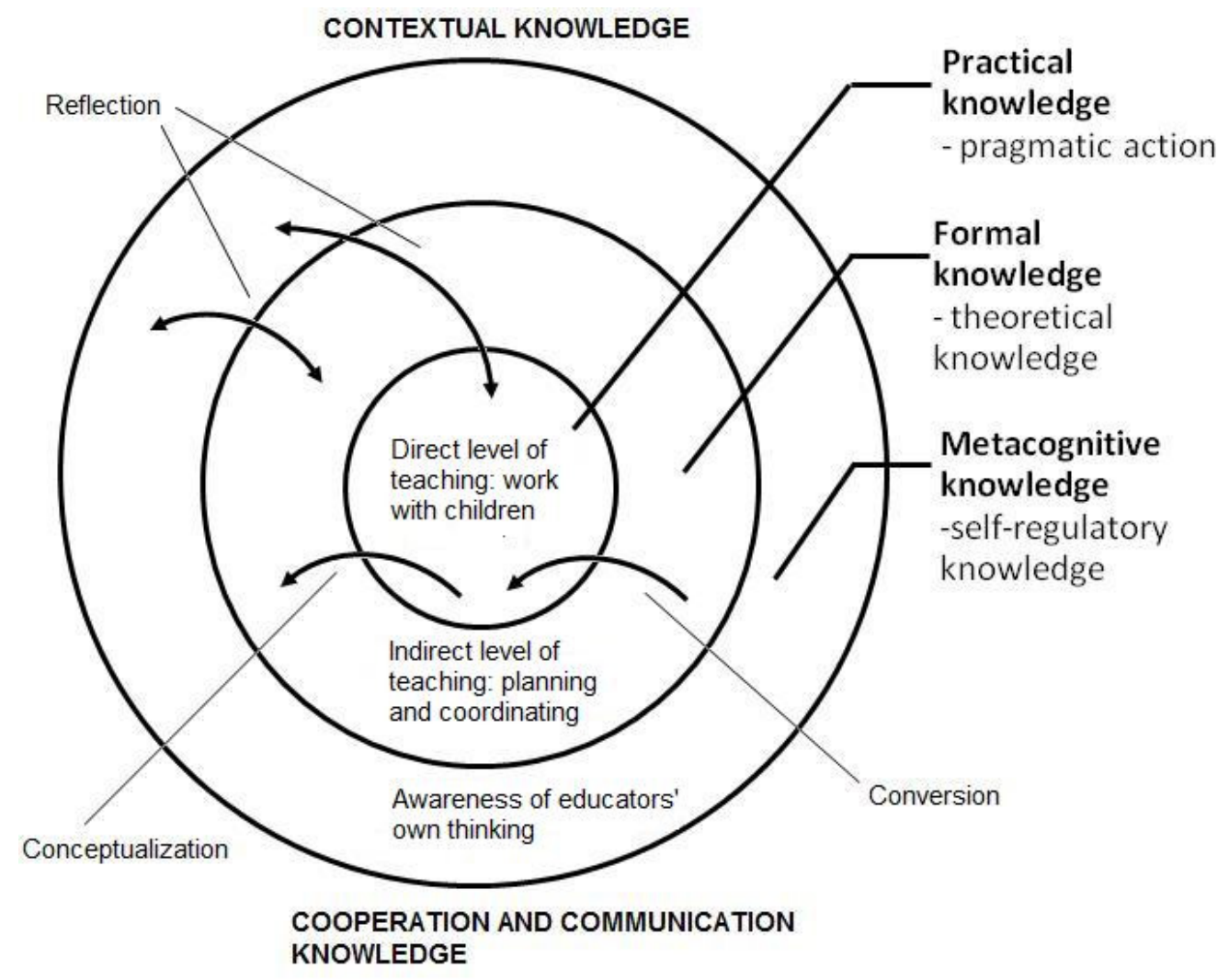

Figure 1. The Principal Components of Early Childhood Educators' Expertise. 